\title{
Public Relations Functions for Sugar-Salt-Fat Consumption Control Programs Planning
}

\author{
Prita Suci Nurcandrani ${ }^{1, a)}$ Yudi Sudiana ${ }^{2)}$ Ayu May Lisa ${ }^{3)}$ \\ ${ }^{1}$ Program Studi Ilmu Komunikasi, Universitas Amikom Purwokerto, Indonesia \\ a) author correspondence: prita.suci@amikompurwokerto.ac.id \\ ${ }^{2}$ Program Studi Ilmu Komunikasi, Universitas Amikom Purwokerto, Indonesia \\ ${ }^{3}$ Program Studi Ilmu Komunikasi, Universitas Amikom Purwokerto, Indonesia
}

DOI: https://doi.org/10.18196/ikm.11211

Article Info

Article history:

Received 25 Feb 2021

Revised 3 Apr 2021

Revised 29 Apr 2021

Revised 24 May 2021

Revised 7 Sep 2021

Revised 5 Oct 2021

Accepted 14 Oct 2021

\section{ABSTRACT}

Non-Communicable Diseases such as stroke, diabetes mellitus, heart attack, and hypertension have increasingly lurked in Indonesia. The excessive consumption of sugar, salt, and fat (SSF) is the trigger for that case, and the government tries to take precautions for people from 13 to 18 years of age. Emphasizing on preventive health communication efforts, this study intended to assist the health promotion program of Puskesmas Purwokerto Utara 2 to apply Public Relations functions by providing IEC (Communication, Information, and Education) on controlling SSF in adolescents. This research used in-depth interviews and observations as data collection techniques, with qualitative descriptive methods to analyze the data. The result showed that this Puskesmas (district clinic) is identified as not implementing the SSF Control Program since its health promotion function is still more focused on routine programs. Meanwhile, 1.021 students in this work area need to prevent threatening diseases. Making collaboration with competent partners, Puskesmas may apply the functions of Public Relations in implementing the preventive programs by providing sufficient information about the danger of the excessive consumption of SSF, inviting people to change attitudes and actions, and representing the organization's attitude towards society.

Keywords: Adolescents; Health Promotion; Non-Communicable Diseases; PR Functions; Sugar-Salt-Fat Consumption Control.

\section{ABSTRAK}

Penyakit Tidak Menular seperti stroke, diabetes mellitus, serangan jantung, dan hipertensi semakin mengintai Indonesia. Konsumsi gula, garam, dan lemak (SSF) yang berlebihan dituding sebagai pemicu kasus tersebut, dan pemerintah berupaya melakukan tindakan pencegahan bagi masyarakat yang berusia 13 hingga 18 tahun. Menekankan pada upaya komunikasi kesehatan preventif, penelitian ini dimaksudkan untuk membantu program promosi kesehatan Puskesmas Purwokerto Utara 2 untuk menerapkan fungsi Humas dengan memberikan KIE (Komunikasi, Informasi, dan Edukasi) dalam pengendalian SSF pada remaja. Dengan teknik pengumpulan data wawancara dan observasi mendalam serta metode analisis deskriptif kualitatif, Puskesmas tersebut teridentifikasi belum melaksanakan Program Pengendalian SSF karena fungsi promosi kesehatannya masih lebih terfokus pada program rutin. Sementara itu, 1.021 mahasiswa di wilayah kerjanya perlu dicegah dari penyakit yang mengancam tersebut. Berkolaborasi dengan mitra yang kompeten, Puskesmas dapat menerapkan fungsi Humas dalam melaksanakan program preventif dengan memberikan informasi yang cukup tentang bahaya mengonsumsi SSF yang berlebihan, mengajak masyarakat untuk mengubah sikap dan tindakan, dan mewakili sikap organisasi terhadap masyarakat.

Kata Kunci: Remaja; Promosi Kesehatan; Penyakit Tidak Menular; Fungsi Hubungan Masyarakat; Pengendalian Konsumsi Gula-Garam-Lemak. 


\section{INTRODUCTION}

Non-Communicable Diseases threatened Indonesia throughout 2018 to 2020, and stroke as one of the kinds increased its number of sufferers from 7\% to 10.9\%. Within the periods of 2013 to 2018, the prevalence of diabetes mellitus was $6.9 \%$ to $8.5 \%$ (predicted to be $11.3 \%$ in 2030), hypertension was $25.8 \%$ to $34.1 \%$, and heart attacts was $1.5 \%$ (Riskesdas, 2018). Overall, the excessive consumption of sugar, salt, and fat (SSF) is accused of the trigger for that case. The stipulation of Regulation of the Minister of Health of the Republic of Indonesia No. 30 of 2013 concerning the inclusion of information on sugar, salt, and fat (SSF) content as well as health messages for processed and readyto-eat foods considers that the public needs to be protected from the risk of Non-Communicable Diseases (NCDs), especially hypertension, stroke, diabetes, and heart attacks. The age indicated as potentially threatened with the disease is 13 to 18 years, commonly referred to as the millennial generation (Kemkes, 2019).

Meanwhile, The Nusantara Movement Program to Reduce Obesity Rates (GENTAS) involves the community to prevent obesity as a risk factor for NCDs covering the following strategic areas.

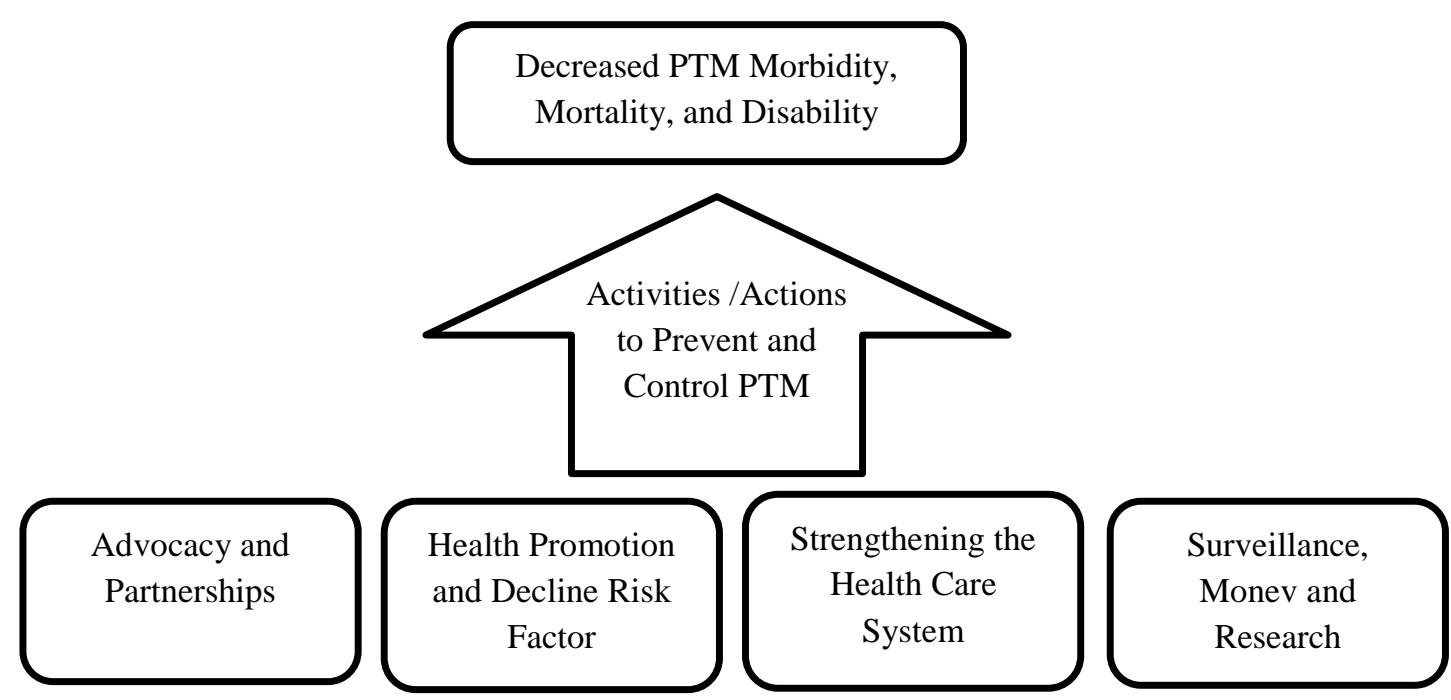

Figure 1. NCDs Prevention and Control Activities

The first area includes advocacy activities and cross-sectoral partnerships to increase and accelerate the response to the epidemic of NCDs. Since the determinants and risk factors for NCDs are in the non-health sector, the efforts to overcome them are unlikely to succeed without support from related sectors. The expected result of the activities is an increase in political commitment and the functioning of an effective cross-ministerial coordination mechanism, and the availability of resources for the program on an ongoing basis.

The second area aims to develop interventions in the community to reduce a number of significant risk factors by cultivating a Clean and Healthy Lifestyle (CHL) to reduce consumption of tobacco products, alcohol, and SSF intake, and increase physical activities and consumption of fruits and vegetables. Meanwhile, strengthening the Health Service System in the third area reinforces the primary health care system. The implementation of this activity will increase public access to NCDs countermeasures services, community, and individuals. Areas of Surveillance, Monitoring and Evaluation, and NCDs research aim to increase the availability and utilization of data for policy and program development. The regional strategy is a reference used to develop a national strategy for handling NCDs with adjustments based on existing needs and capacities (p2ptm.kemkes, 2018).

The legal basis and guidelines for GENTAS are Presidential Instruction No.1 of 2017 concerning the Healthy Living Community Movement, the 20115-2019 RPJMN RENSTRA Book, and the Minister of Health Regulation No. 71 of 2015 concerning the Prevention of NCDs. The target of the GENTAS program is citizens aged fifteen years and over who live in the area concerned (p2ptm.kemkes, 2019).

Another important issue in the Regulation of the Minister of Health of the Republic of Indonesia No. 30 of 2013 is an effort to educate the public by including information on SSF content and health 
messages for processed and ready-to-eat foods. Accordingly, Puskesmas, as the first-level service center for driving health-oriented development of family and community empowerment in the country, should provide initial information about the importance of maintaining a healthy diet and wise consumption of processed and ready-to-eat foods. Then, Communication, Information, and Education (IEC) activities need to be packaged as a promotional and preventive effort for the community.

Based on the Ministerial Regulation above, Puskesmas needs to conduct appropriate IEC interventions for adolescents to control SSF consumption. The spread of ready-to-eat foods has made teenagers disregard selectivity in consuming them. The COVID 19 pandemic condition causing people to carry out activities from home increases the number of NCDs if not alert. Further, online school activities also bring about teenagers lazy to move, making the threat of NCDs is even more significant.

According to nutritionists working for the Puskesmas Purwokerto Utara 2, IEC intervention efforts have never been organized in their work area. Geographically, the Puskesmas is responsible for adolescent health in two schools, namely SMPN 9 Purwokerto and SMK TI Bintra Purwokerto, with 1,021 students. This is a big challenge for the Puskesmas to make preventive and promotive efforts. This study aims to formulate SSF control program planning in adolescents using the Public Relations function approach. Basically, all Public Relations activities depart from the communication process, and this paper emphasizes preventive health communication efforts. It is hoped that it will also enrich the domain of communication science in the health sector.

A number of studies on adolescent health promotion related to NCDs have been conducted. One of them is research revealed that using the correct terminology in nutrition education programs and behavior change campaigns is essential to optimize the effectiveness of these efforts. The study's results suggested that different terms for unhealthy foods can mean very different things. A detailed understanding of what this means is necessary to ensure that nutrition guidelines and health promotion campaigns use the appropriate terminology (Truman, Emily, 2019).

Further, placing the healthy manner configuration within the family circumstances may encourage adolescent adjustment toward a sound lifestyle. Many scientific references are discussing healthy lifestyles and parenting uncovered some astonishing facts. The facts include the pertinence of regaining the biopsychosocial richness of well lifestyles, the need to apply a dialogue action to resolve incongruity between youngsters and their parents, and the competence of the personal parenting approach to foster adapted teenagers behavioral freedom, and with it conserve healthy lifestyles in the long term (Alonso-Stuyck, 2020). Meanwhile, healthy lifestyles are multidimensional and dynamic; and children demonstrate different compositeness of risks and protections. Family aspects, such as resources and parenting, the form of earlier health lifestyles, affect subsequent lifestyles. Results identify that advancement and contexts encourage changes in health lifestyles. As family aspects abate to influence in line with age, some school and peer influences begin to arise. (Mollborn, Stefanie, 2018).

A study examined adolescent health promotion with health and education interface concentrating on the actions of the Brazilian School Health Program. This qualitative study was carried out in 2015 with professionals working for the Regional Executive Coordination IV in Fortaleza, Ceará. The data acquired by interviews were processed in the ALCESTE program. The results identified that 17 health professionals and 22 education professionals engaged in the research. The organization of instinctive order brings about incongruity in the arranged visits and health accomplishment in the school. The arduousness in the execution of the School Health Program were indicated by the insufficient knowledge, insufficient planning among the sectors and the different boundary in the region. The study concluded that the professionals' insufficiency of knowledge concerning the program and the insufficiency of action planning assure the incoherence of the education and health sectors. However, they show the likelihood of this intersectoral action (Gonçalves, Eysler, Maia Brasil, Raimunda Magalhães da Silva, Maria Rocineide Ferreira da Silva, Dafne Paiva Rodrigues, 2017).

In addition, social media is widely used among adolescents. However, few researchers have further suggestions on how social media can be applied to boost teen health. The Philadelphia Ujima $^{\mathrm{TM}}$ Coalition, supported by the Office on Women's Health, carried out a needs appraisal to examine social media as a health communication devise. This study intended to identify the use of social media in practices, approach to effectively involve teens on social media, and advice for adolescent's health promotion on social media. It is identified that from $94.6 \%$ of adolescents using social media, only $3.5 \%$ reported seeking health-related information. However, when questioned 
about particular issues (i.e., fitness, sexual health, nutrition), $66.7 \%$ to $91.7 \%$ reported health information tracking. Although many youngsters could not recognize valid information sources, they wanted health messages to be alluring and adapted. Social media assure itself as an adequate health communication device. However, information must be dependable and arranged in attractive messages designed to fulfill adolescents' various needs. The findings of this study indicate the critical need to further innovation on how social media platforms may boost its usage in health advancement (Marie Plaisime, Candace Robertson-James, Lidyvez Mejia, Ana Núñez, Judith Wolf, 2020).

Junk foods are identified as rich in calories, salt, and fat, and consuming them excessively will cause all kinds of health problems. It is recommended that schools and communities implement awareness programs. The findings of the study indicated that more girls $(67.0 \%)$ consume fast foods than boys, about half (49.0\%) of the participants consume fast foods as an alternative to main meals, and more than half of the participants $(63.0 \%)$ consume soft drinks every day. An even more significant greater proportion of the participants $(42.0 \%)$ have urinary tract infections, and it may be related to chips, while soft drinks are the most attractive food (Pettigrew, S., Talati, Z., \& Pratt, 2017).

A research conducted to determine awareness of stroke symptoms and risk factors in middle and high school students in one institution identified that most students are unaware of all the risk factors and symptoms associated with stroke. Although this study was limited to only one school, the findings indicated a need to educate middle and high school students about stroke risk factors, symptoms, and acute interventions (Umar, Abdullah B, Tracy J. Koehler, Reian Zhang, Veronica Gilbert, Muhammad U. Farooq, Alan T. Davis, 2019).

Junk food consumption among adolescents has been recognized as asevere health problem in the world. A study was aimed to assess the effectiveness of an educational intervention program (interactive lecture) based on the theory of planned behavior (TPB) in reducing junk food consumption among school adolescents in Birgunj Metropolitan City, Nepal. Using structured questionnaires, the study concluded that the intervention program positively affects perceptions of uncontrolled behavior in school adolescents (Upendra Kumar Singh, Nirmal Gautam, Tulsi Ram Bhandari, 2020).

Proper nutrition has an essential role in protecting individuals from various diseases, especially chronic ones, and increasing physical and intellectual efficiency. An inquiry was conducted to know the effect of nutrition education on elementary school students' knowledge, attitudes, and behavior on the consumption of junk foods. The results showed that the intervention has a positive effect on nutritional patterns. The conclusion was that interventions are effective in enhancing students' knowledge, attitudes, and behavior.

Referring to previous research, this study aims to intervene in healthy eating in adolescents using the Public Relations function approach. The Puskesmas carry out the intervention to adolescents who have a high potential for stroke due to their excessive consumption of SSF. This study is intended to combine the IEC program with Public Relations methods in intervening the audience (Vardanjani, Ali Esmaeli, Mahnoush Reisi, Homamodin Javadzade.

Inevitably, the organization's public relations agency is very important, related to the work affairs handled, and very fundamental. Therefore, it is proper for Public Relations to understand its function ideally. Edward L. Bernays revealed that the three main functions of Public Relations are providing information, persuading the public to change attitudes and actions, and representing organizational attitudes towards the public and vice versa. The public in an organization is divided into internal and external publics; primary public; secondary public and marginal public; and traditional and future publics. The next public is the silent majority and vocal minority; lastly, the public opponent, proponent, and uncommitted public (Syarifuddin dan Suryanto Gassing, 2016).

Littlejohn (2017) introduced Innovation Diffusion Theory, which examines how individuals and organizations adopt a number of new ideas, practical things, or objects. Everett M. Rogers developed a very comprehensive model of how several innovations are adopted. The diffusion of innovation theory is widely used in development communication, especially in developing countries such as Indonesia or the third world. Diffusion is a special type of communication that deals with the spread of messages as new ideas. Adopters are grouped into innovators, early adopters, early majority, late majority, and laggards. Since the SSF control pattern program for adolescents has not been intervened by the Puskesmas, it is necessary to take the first step in IEC activities. The diffusion of innovation theory becomes a foothold in analyzing a communication planning process, starting from the Puskesmas as innovators to adopters. 
This study emphasizes the function of public relations in the realm of health communication. The PR function here is an extension of government programs, especially in the health sector for adolescents. PR is not only a tool for campaigning for SSF control programs. However, it is also involved in managerial functions, namely formulating programs and maximizing PR communication media that are in accordance with the media used by teenagers.

\section{METHODS}

This study applies a qualitative-descriptive method and uses triangulation of data sources. Observations and in-depth interviews are carried out with the Health Promotion team at Puskesmas Purwokerto Utara 2, the School Health Section (UKS) at SMPN 9 Purwokerto, SMK TI Bintra Purwokerto, and eight teenagers who live in the work area of the Puskesmas as an implementation of the use of triangulation of data sources. Meanwhile, other data are obtained from written documents such as Basic Health Research, Government Regulation of the Ministry of Health of the Republic of Indonesia, Presidential Instruction, and Puskesmas Health Promotion Program Documents.

\section{RESULT AND DISCUSSION}

\section{Result}

Puskesmas functions as the first-level service center for driving health-oriented development of family and community empowerment. The types of the health services are adjusted to the capabilities of each Puskesmas. However, there are compulsories added known as the basic six covering a series of efforts: health promotion, environmental health, maternal and child health, and family planning. Improvement of public nutrition, prevention and eradication of infectious diseases, and treatments (https://dikes.badungkab.go.id/puskesmaskutaselatan/page/read/94). The supremacy of a predominant health care design for health treatment delivery is greater access to required services; preferable grade of care; a greater focus on deterrence; early management of health complications; and aggregate improvements in health and reduce morbidity as a result of primary health care delivery (Yeravdekar, 2013). So far, Puskesmas has been making more curative efforts due to the lack of public awareness to adopt a healthy lifestyle. Nutritionists working for the Puskesmas conveyed: "Maybe the conditions and socio-economic background, as well as education, influence their thinking patterns. If they are not sick, they are not aware. "

Planning for preventive activities is a big challenge for the Puskesmas, while Communication, Information, and Education (IEC) activities are emphasized in strategic prevention interventions. The SSF Control Program emphasizes the age range of adolescents from 13 to 18 years as the target of intervention, and the School Health Unit in the work area of Puskesmas Purwokerto Utara 2 informs there are a total of 1,021 adolescents summarized in the following table:

Table 1. Total Student of SMP N 9 PURWOKERTO

\begin{tabular}{llll}
\hline Class & Male & Female & Amount \\
\hline Class VII & 136 & 124 & 260 \\
\hline Class VIII & 141 & 122 & 263 \\
\hline Class IX & 138 & 131 & 269 \\
\hline Total & 415 & 277 & 692 \\
\hline \multicolumn{4}{c}{ Table 2. Total Student of SMK TI BINTRA } \\
\hline Class & Male & Female & Amount \\
\hline Class X & 66 & 31 & 97 \\
\hline Class XI & 91 & 30 & 119 \\
\hline Class XII & 74 & 37 & 111 \\
\hline Total & 231 & 98 & 329
\end{tabular}

The number of adolescents which reaches over a thousand need special attention to handling. However, the SSF Control Program has never been implemented, as stated by the nutritionist at the Puskesmas: "We have not touched the SSF Control program at all. So far, we only conduct routine 
government program interventions such as giving vitamins and iron and routine examinations for adolescents. “

Given that excess SSF in adolescents can increase the risk of degenerative diseases, it is necessary to take preventive efforts to deal with it from the beginning. The emphasis on the Nusantara Movement Program to Reduce Obesity Rate (GENTAS) is one of the solutions for planning the initial SSF control efforts. "We may implement GENTAS activities with a strategy that is tailored to the conditions and backgrounds of young people here," revealed the Puskesmas Health Promotion Section. Meanwhile, observation and interviews are also carried out on three adolescents to confirm whether they have received the interventions. An adolescent informant (AW, 17 years) conveyed: "We have never received any information from the Puskesmas about the dangers of excess SSF." Added by a colleague AW (AK, 17 years): "So far, we are often only given vitamins and routine check-ups; there is no information about SSF control for adolescents." Another young informant (EN, 14 years) also stated something similar: "It seems that there has never been any health education about that."

\section{Discussion}

In the view of Public Relations, establishing a strategy or intervention in a program needs to identify the audience first. The aim is to see the appropriateness of the target audience, create a priority scale, select the most suitable media, and prepare a series of messages in such a way as to be efficient and quickly accepted (S. and S Gassing, 2016). The primary audiences of this study are adolescents aged 13 to 18 years who would later become the main or most important targets. These main targets fall into the category of external targets of the Puskesmas. Viewed from the diffusion theory of innovation, this public falls into the early majority category with characteristics of full consideration and high internal interaction. Diffusion of innovation theory is a theory that examines how new ideas, practical things, or objects are adopted by individuals, and this theory is widely used as an approach in development communication, especially in developing countries or the third world such as Indonesia and its colleagues (Littlejohn, 2017). Even though numerous theories are worthwhile in explaining occurrences in the domain of medical informatics, diffusion of innovation represents one such theory that can be appropriate with a broad number of medical informatics study focused on new technologies or work processes (Weigel, 2012). Aspects of the study and practice paradigm known as the diffusion of innovations are wearable to the complicated contexture of health care, for both expository and interventionist purposes (Dearing, 2018)

The formulation of a strategic planning approach to the Public Relations function is to provide information to predetermined audiences and change the expected attitudes and behaviors. The last function is to represent the organization's attitudes or process an object into a concept/idea, so that it raises a meaning that must be adequately understood by audiences and in accordance with what the program planner wants to convey.

\section{The Function of Public Relations to the Providing Information}

Accessible, high-quality health information constitutes a primary constituent of health literacy. A structure to rectify health information would support the efforts of government, services and consumer organizations to cater to literacy needs more consistently, improving standards and eventually increasing the participation by consumers and carers in health decision making and selfmanagement. The perfection and provision of health information materials needs to be systematized and bolstered up by infrastructure, requiring leadership, cultural change, standards and skills development (Hill, 2018).

Providing information to audiences in health sector is closely related to the term IEC or Communication, Information, and Education. This term is used by the Puskesmas Health Promotion Division to design pre-defined health program marketing. Designing, implementing, and evaluating health communication campaigns is a complicated task with numerous defiances, accumulated manifold in developing country settings (Sood, 2014). Before designing SSF Control for adolescents, it is necessary to identify how the individuals relate to their environment. Saparinah Sadli described the relationship between individuals and their social environment as follows (Notoatmodjo, 2018). 


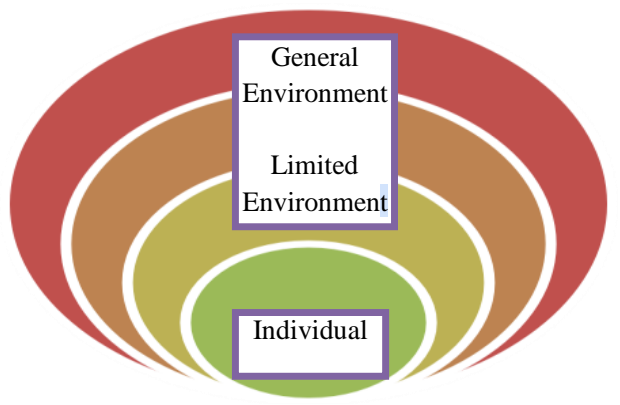

Figure 2. Relationship between Individuals and the Social Environment

In the smallest circle, namely individual behavior, it is necessary to know its attitudes and habits closely related to the environment. In the second circle or family environment, Puskesmas must understand the habits or behavior of each family member regarding health. In the limited environment, Puskesmas must also examine the community's traditions, customs, and beliefs regarding health. The last one is to study the general environment that affects the operation of Puskesmas, including government policies in the health sector, health laws, several health programs, and the like. In line with this, the Puskesmas Health Promotion Section stated specifically: "People in each region have different health behaviors. This may be influenced by the level of education, local wisdom, and personal experience. Or it could also be the pressure that comes from family and colleagues." Accordingly, individual behavior is influenced by the environment ranged from family to the general environment. In program planning, research needs to be done to see aspects or people who influence the health behavior of adolescents in their environment. Advocacy activity can be more appropriate for the implementation of IEC because it is a form of approach to people considered to influence their environment or territory.

In terms of communication science, advocacy is interpersonal and mass communication aimed at policymakers or decision-makers at all social levels. Inclusively, advocacy aims at political commitment, policy support, social acceptance, and system support (Notoatmodjo, 2018). The advocacy model applied to the SSF Control program for Adolescents can be described as follows:

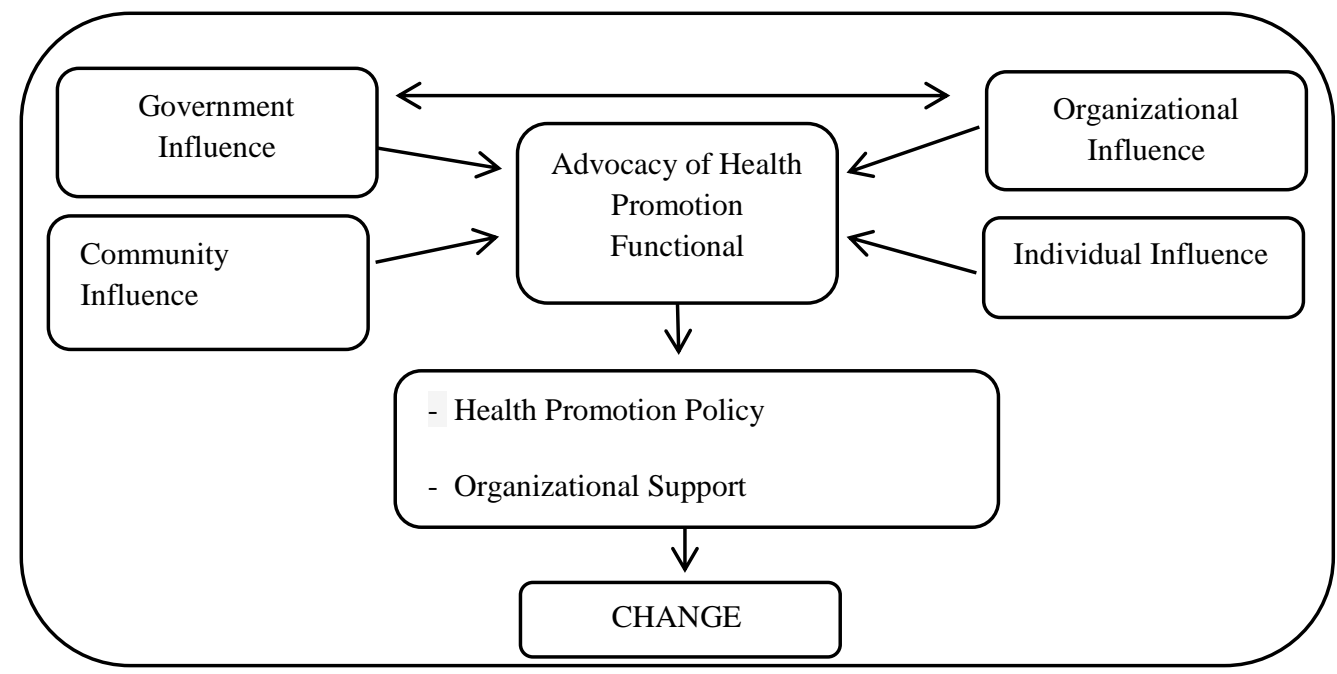

Figure 3. Health Promotion Functional Advocacy Model

Government Influence and Organizational Influence serve as the foremost guidelines for health promotion officers in carrying out their primary duties based on policies or regulations issued by the government. Furthermore, Community Influence and Individual Influence are the main supporters of the operationalization of adolescent health promotion activities. These four pillars determine the 
success of health promotion functional workers in providing assistance and accessibility of adolescent health information.

Advocacy methods and techniques review every presidential instruction, government regulations, Riskesdas, and the GENTAS program. After that, the officers dig up information about adolescent health behavior from the School Health Unit (SHU) administrators of SMPN 9 Purwokerto and SMK TI Bintra Purwokerto to obtain support or commitment form of permits related to SSF control activities. A study entitled Fast Food Consumption among Teenagers Aged Between (13 To 25) Years Old and Their Effect on Health in Derna-Libya also recommended schools and communities implement awareness programs about its bad effects on fast food consumption. Excessive consumption of junk foods will cause various health problems. Most teenagers eat junk foods that have harmful effects later in life. Another finding revealed that more girls $(67.0 \%)$ consume fast food than boys (Younis, Fareha Hamd, 2019). Media campaigns concerning sugary drinks and obesity may be effective for heightening awareness about added sugars in beverages, augmenting knowledge about health problems associated with excessive sugar consumption, and encouraging behavioral intentions to reduce soda and sugary drink consumption (Boles, 2014)

The issue described above can become a consideration and input in strategic planning. Confirmation is needed if the data and information obtained are deemed insufficient. Approaches, observations, and interviews with several adolescents to represent their health behavior patterns are needed to formulate the right profile. In the realm of Public Relations, this approach is called the segmenting, targeting, and positioning stages.

The next stage is to determine the right advocacy media for the target, namely adolescents aged 13 to 18 years, as they can easily access information from social media and the internet. However, many digitized health promotion strategies focus on individual cognizance for health and fail to identify the social, cultural, and political dimensions of digital technology exertion (Lupton, 2014). Facing the challenges and opportunities of emerging technologies, a Public Relations approach is needed in the correct communication planning program in the SSF control program. Virtual simulations approve people to view the future unfortunate health effects of present dietary choices concretely. Virtual models were the most effective approach for elevating perceived likelihood, perceived susceptibility, involvement, and soft drink consumption over time (Ahn, 2016). This is corroborated by the findings of research entitled Unhealthy food consumption in adolescence: role of sedentary behaviors and modifiers in 11-, 13- and 15-year-old Italians, which discussed the importance of emphasis on developing adolescent skills in accessing and using media and technology appropriately (Borraccino, A., Lemma, P., Berchialla, P., Cappello, N., Inchley, J., Dalmasso, P., Charrier, L., Cavallo, F., 2016).

One of the factors influencing the behavior change process is influencers. Many industries use influencer marketing to promote their products and services. The current trend of companies is seeing the popularity of influencers by considering the number of followers and seeing the true profile of trusted influencers in the eyes of potential customers. Meanwhile, the practical application of social media in Public Relations campaigns can deliver conversion, simplify brand positioning, and preserve continued brand fortune (Allagui, 2016). So, Public Relations must understand social media measurement to determine the value of an influencer marketing program, whether paid or unpaid. Social media measurement tools can identify the ideal influencer (Arief, 2016). Equipping cultural aspects endemic to social media, such as popular influencers and memes, is a promising strategy for elevating health campaign interest and engagement (Kostygina, 2020).

\section{Public Relations Functions to Represent the Organization's Attitude}

Consuming junk foods can make children stop eating healthy foods both at school and at home. The practice of high consumption of junk foods such as maggi noodles, burgers, pao-bhaji, sandwiches, hot dogs, patties, pastries, popcorn, potato chips, chocolate, biscuits, muffins, toast, kulcha-channa, samosas, and carbonated drinks has become a common feature of the diets of adolescents worldwide. They often eat fast food and consume fewer fruits, vegetables, and dairy products, so that the potential for obesity to occur. Obesity is a significant public health problem that arises worldwide among adolescents. The issue of obesity is one of the most effective means of changing their eating habits without affecting their sentiments. Nutrition counseling regarding the importance of a balanced diet, the harmful effects of junk food will help to curb junk food addiction and improve its nutritional status (Arya, Geeta, 2013). 
Based on the results of the above research and the Nusantara Program to Reduce Obesity Rates (GENTAS) from the Indonesian government, Puskemas Purwokerto Utara 2 should prioritize the intervention program for SSF control. The program is equipped by legal basis and guidelines, Presidential Instruction No.1 of 2017 concerning Healthy Living Community Movement, the RPJMN RENSTRA Book 20115-2019, and Regulation of the Minister of Health No 71 of 2015 concerning Prevention of NCDs has a target of citizens aged fifteen years and over. Considering that the work area of Puskesmas Purwokerto Utara 2 houses at least 1.021 adolescents who attend SMPN 9 Purwokerto and SMK TI Bintra, the Puskesmas should design synergistic activities which are the implementation of organizational attitudes. The representation of the Puskesmas' attitude can be shown by implementing several strategic areas in the Control and Prevention of NCDs. Areas that can be adopted include Strengthening Health Service Systems and Surveillance, Monitoring, Evaluation, and Research in the Field of NCDs (p2ptm.kemkes, 2019).

Hardening health teams' leadership and management abilities through team-based approaches focused on selected challenges will improve health service delivery results (La Rue et al., 2012). Not only adopting, Puskesmas must also be able to adapt to the two areas mentioned above. Strengthening the health service system will increase public access in overcoming NCDs. The following areas are Surveillance, Monitoring, and Evaluation, as well as Research on NCDs. This activity aims to increase the availability and use of data for policy and program development. In fact, this regional strategy becomes a reference in developing a national strategy for dealing with NCDs with adjustments based on needs and capabilities (p2ptm.kemkes, 2019).

At the Puskesmas level, this area can be adapted by looking at adolescents who live and attend school in the area covered. Although the characteristics of adolescents can be generalized, there is still uniqueness of local adolescent habits. It is influenced by lifestyle, socio-cultural background, family education, and consumption patterns of mass media. Ameliorating nutrition knowledge in children and young adolescents may convert into educating them in good dietary practices. Further, nutrition intervention programs should also entail parents elevate the entire family's dietary quality and nutritional habits (Grosso et al. 1, 2013).

Confirmed in previous research, various socio-cultural influences play an essential role in applying unhealthy dietary practices and sub-optimal physical activity behavior. Food preferences based on adolescent taste were identified and prioritized in the family by mothers. The popularity of street food and better understanding of the importance of food hygiene and safety are in contrast with narrow perceptions of balance and diversity in diets. Peer influence, inadequate schooling and community food environment, internalization, and rigor of gender norms are found to have a significant influence. These findings highlight the primary targets for community-based nutrition interventions, and support comprehensive considerations related to socio-cultural factors in formulating strategies to promote healthy eating behavior and physical activity among adolescents (Islam, M. R., Trenholm, J., Rahman, A., Pervin, J., Ekström, E. C., \& Rahman, 2019).

Departing from these facts, the Puskesmas can develop specific strategies to be able to intervene in the SSF control program. Inevitably, the strategies designed should also be adjusted to the capabilities and availability of human resources and technology owned.

\section{Public Relations Functions to Change Attitudes and Actions}

The function of Public Relations, namely how to change attitudes and actions of program targets. Health Promotion is known as building and creating an atmosphere to establish an opinion or a social environment that encourages individual community members to carry out the introduced behavior. Someone will be motivated to do something if the social environment they are located in has a positive opinion on the behavior (p2ptm.kemkes, 2018). Previous research stated that statistically, peer education significantly affects attitudes about nutrition and obesity and reduces fast food consumption habits (Said I, Hadi AJ, Manggabarani S, Tampubolon IL, Maryanti E, 2020).

The atmosphere building aims to create a supportive atmosphere by mobilizing the community's participation and partnership. The Community Based Health Efforts (UKBM) implements participatory efforts to be applied as a marketing effort for health programs. This effort is not easy to make. If community participation is good, it will encourage the program optimally. Conversely, if community participation is low, then not only can the health program not be helped, but UKBM will become a burden for field officers to support it. 
Health promotion implementers agree that community participation is the key to the success of community health efforts in Puskesmas. However, it is precisely the one that most Puskesmas people complain about. Complaints occur because they are fixated on only one method or are accustomed to dealing with certain groups. To overcome this problem, they need to develop insights and improve their skills in dealing with various characters, socio-economic conditions, and community education.

Previous studies emphasized that young women with low socio-economic positions have limited knowledge about healthy lifestyles. Hence, it is necessary to understand better the complexities of handling the health behavior of young women in gaining insights on how to develop health promotion in accordance with their daily realities (Lems, Eva, Femke Hilverda, Asia Sarti, Lisa van der Voort, Amber Kegel, Carina Pittens, Jacqueline Broerse, 2020).

Another study uncovered that watching online videos and playing computer games are behaviors associated with a higher likelihood of consuming fast food in rural and urban areas, with a higher chance in rural areas. Surfing the internet is associated with a higher likelihood of being overweight in both rural and urban areas. The study result also identified that children living in rural areas spend more time playing computer games, watching TV and videotapes, but less time doing homework than their urban counterparts. The study was conducted to develop adequate health promotion policies in rural and urban areas (Hansstein, Francesca Valeria, Yu Hong, 2016).

Health administrators also need to master various methods and utilize a variety of technologybased multi-media to facilitate the delivery of varied programs. Nutrition education through booklet media in specific communities has an effect on increasing knowledge, reducing consumption of fast foods, calorie intake, and body mass index (BMI) in adolescents (Said I, Hadi AJ, Manggabarani S, Tampubolon IL, Maryanti E, 2020).

The success of Community Based Health Efforts (UKBM) in adolescent behavior change programs in controlling SSF can be supported by a partnership program. A Health in all policies approach needs creating and sustaining intersectoral partnerships to foster population health (Corbin et al., 2014). Community affiliation or intersectoral partnerships have long been encouraged for the promotion of population health. A higher appreciated quality of cooperation within the partnership increases the results of a well-functioning partnership by hardening their recognition of a healthpromoting community and empowerment (Cicognani, 2020).

Nutritionists at Puskesmas Purwokerto Utara 2 emphasized that partnerships are still very minimal because the health promotion function is more focused on routine programs at Puskesmas and implementing top-level policies, which are quite time-consuming. A collaboration between professional associations and/or with other non-governmental organizations is necessary to overcome this problem.

Crucial aspects that should be noticed in partnership patterns are knowledge and ego of each party. For example, consolidation of health information systems in Muhammadiyah is difficult to actualize since the sectoral ego's high potential in managing the Muhammadiyah Healthcare Charity Venture (AUMKES) (Rahmawati, 2020). The professionals' shortage of knowledge regarding the program and the insufficiency of action planning assure the disarticulation of the education and health sectors. However, they show the possibilities of this inter-sectoral practice (Brasil et al. 1, 2017). Nevertheless, it is expected that the health promotion officers of the Puskesmas and partners can work together to achieve common goals by communicating, informing, and educating adolescents to control patterns of nutritional intake, especially SSF.

One of the partnership implementation activities emphasizes the importance of including information about SSF content and health messages for processed and ready-to-eat foods. It is appropriate to collaborate with BPOM of Banyumas Regency to provide education and training to food business players in the work area of the Puskesmas.

This is confirmed by research that stated that sustainable nutrition education is needed to change the behavior of limiting fast food consumption. The incessant promotion of fast foods raises the perception that fast food is a trend among adolescents. Nutrition education based on Planned Behavior Theory is proven to influence attitudes, subjective norms, and intensity but does not change the behavior to limit fast foods (Handarbeny, 2017). 


\section{CONCLUSION}

Basically, all Public Relations activities depart from the communication process. This paper focuses on preventive health communication efforts to assist the health promotion program planning of Puskesmas Purwokerto Utara 2 by applying Public Relations functions of IEC (Communication, Information, and Education) for controlling SSF in adolescents. Puskesmas Purwokerto Utara 2 has not intervened in the SSF control program for adolescents in its work area. This is because the health promotion function is still more focused on routine Puskesmas programs, even though there are 1,021 students under the responsibility of the Puskesmas in preventive efforts to tackle degenerative diseases that threaten the health of adolescents. Puskesmas efforts can borrow Public Relations functions in implementing programs such as providing information to the public, persuading the public to change attitudes and actions, and representing the organization's attitude towards the public, and vice versa. Implementations that can be carried out, among others, (1) Emphasizing advocacy using influencers as a reflection of the function in providing information to adolescents; (2) Prioritizing GENTAS program to represent the attitudes of organization (Puskesmas), and (3) Establishing the partnerships with professionals and non-professionals to foster an atmosphere as public relations function to change the attitudes and actions of adolescents in controlling SSF consumption.

\section{REFERENCES}

Ahn, S. J. G. (2016). Virtual exemplars in health promotion campaigns. Journal of Media Psychology. Allagui, I., \& Breslow, H. (2016). Social media for public relations: Lessons from four effective cases. Public relations review, 42(1), 20-30.

Alonso-Stuyck, P. (2020). Parenting and Healthy Teenage Lifestyles. International Journal of Environmental Research and Public Health, 17.

Arief, N. (2016). Public Relations in the Era of Artificial Intelligence. Simbiosa Rekatama Media.

Arya, Geeta, S. M. (2013). Effects of Junk Food \& Beverages on Adolescent`s Health. Journal of Nursing and Health Science, 1(6), 26-32.

Boles, M., Adams, A., Gredler, A., \& Manhas, S. (2014). Ability of a mass media campaign to influence knowledge, attitudes, and behaviors about sugary drinks and obesity. Preventive Medicine, 67, S40-S45.

Borraccino, A., Lemma, P., Berchialla, P., Cappello, N., Inchley, J., Dalmasso, P., Charrier, L., Cavallo, F., \& I. H. 2010 G. (2016). Unhealthy food consumption in adolescence: role of sedentary behaviours and modifiers in 11-, 13- and 15-year-old Italians. European Journal of Public Health, 26(4), 650-656.

Brasil, E. G. M., Silva, R. M. D., Silva, M. R. F. D., Rodrigues, D. P., \& Queiroz, M. V. O. (2017). Adolescent health promotion and the School Health Program: complexity in the articulation of health and education. Revista da Escola de Enfermagem da USP, 51.

Cicognani, E., Albanesi, C., Valletta, L., \& Prati, G. (2020). Quality of collaboration within health promotion partnerships: Impact on sense of community, empowerment, and perceived projects' outcomes. Journal of community psychology, 48(2), 323-336.

Corbin, J. H., Jones, J., \& Barry, M. M. (2018). What makes intersectoral partnerships for health promotion work? A review of the international literature. Health promotion international, 33(1), 4-26.

Dearing, J. W., \& Cox, J. G. (2018). Diffusion of innovations theory, principles, and practice. Health Affairs, 37(2), 183-190.

Gassing, S. dan S. (2016). Public Relations. ANDI.

Gassing, Syarifuddin dan Suryanto. (2016). Public Relations. ANDI.

Gonçalves, Eysler, Maia Brasil, Raimunda Magalhães da Silva, Maria Rocineide Ferreira da Silva, Dafne Paiva Rodrigues, M. V. O. Q. (2017). Adolescent Health Promotion and The School Health Program: complexity in the articulation of health and education. Journal of School of Nursing.

Grosso, G., Mistretta, A., Turconi, G., Cena, H., Roggi, C., \& Galvano, F. (2013). Nutrition knowledge and other determinants of food intake and lifestyle habits in children and young 
adolescents living in a rural area of Sicily, South Italy. Public health nutrition, 16(10), $1827-$ 1836.

Handarbeny, R. W. dan T. M. (2017). Pengaruh Pendidikan Gizi Berbasis Theory of Planned Behavior untuk Mempromosikan Pembatasan Konsumsi Fast Food pada Siswi. Amerta Nutrition, 10.

Hansstein, Francesca Valeria, Yu Hong, C. Di. (2016). The Relationship between New Media Exposure and Fast Food Consumption among Chinese Children and Adolescents in School: a Rural-Urban Comparison. Sage Journals, 24(3), 40-48.

Hill, S. J., \& Sofra, T. A. (2018). How could health information be improved? Recommended actions from the Victorian Consultation on Health Literacy. Australian health review : a publication of the Australian Hospital Association, 42(2), 134-139. https://doi.org/10.1071/AH16106

Islam, M. R., Trenholm, J., Rahman, A., Pervin, J., Ekström, E. C., \& Rahman, S. M. (2019). Sociocultural Influences on Dietary Practices and Physical Activity Behaviors of Rural Adolescents-A Qualitative Exploration. Nutrients, 11(12).

Kemkes. (2019). Gula Garam Lemak. Http://Www.P2ptm.Kemkes.Go.Id/DokumenP2ptm/Permenkes-No-30-Th-2013-Gula-Garam-Lemak.

Kostygina, G., Tran, H., Binns, S., Szczypka, G., Emery, S., Vallone, D., \& Hair, E. (2020). Boosting health campaign reach and engagement through use of social media influencers and memes. Social Media+ Society, 6(2), 2056305120912475.

La Rue, K. S., Alegre, J. C., Murei, L., Bragar, J., Thatte, N., Kibunga, P., \& Cheburet, S. (2012). Strengthening management and leadership practices to increase health-service delivery in Kenya: an evidence-based approach. Human resources for health, 10(1), 1-7.

Lems, Eva, Femke Hilverda, Asia Sarti, Lisa van der Voort, Amber Kegel, Carina Pittens, Jacqueline Broerse, C. D. (2020). McDonald's Is Good for My Social Life'. Developing Health Promotion Together with Adolescent Girls from Disadvantaged Neighbour hoods in Amsterdam. Children and Society, 34, 204-219.

Littlejohn, S. (2017). Theories of Human Communication. Wadsworth Publishing.

Lupton, D. (2014). Health promotion in the digital era: a critical commentary. Health promotion international, 30(1), 174-183.

Marie Plaisime, Candace Robertson-James, Lidyvez Mejia, Ana Núñez, Judith Wolf, and S. R. (2020). Social Media and Teens: A Needs Assessment Exploring the Potential Role of Social Media in Promoting Health. Sage Journal.

Mollborn, Stefanie, E. L. (2018). Family, Peer, and School Influences on Children's Developing Health Lifestyles. Journal of Health and Social Behavior, 59(1), 133-150.

Notoatmodjo, S. (2018). Metodologi Penelitian Kesehatan. Rineka Cipta.

p2ptm.kemkes. (2018). Buku Pedoman Manajemen Http://P2ptm.Kemkes.Go.Id/Uploads/VHcrbkVobjRzUDN3UCs4eUJ0dVBndz09/2019/03/B uku_Pedoman_Manajemen_PTM.Pdf.

p2ptm.kemkes.

PedumGentas. Http://P2ptm.Kemkes.Go.Id/Uploads/2017/11/PedumGentas.Pdf.

Pettigrew, S., Talati, Z., \& Pratt, I. S. (2017). Health Communication Implications of the Perceived Meanings of Terms used to Denote Unhealthy Foods. BMC Obesity, 4(3).

Rahmawati, W., \& Rasyid, E. (2020). Organization Communication Dynamics in The Process of Integrated Information System in Muhammadiyah Healthcare Charity Venture. Komunikator, Vol.12 No.1 May 2020, 46-54. https://journal.umy.ac.id/index.php/jkm/article/view/8380

Said I, Hadi AJ, Manggabarani S, Tampubolon IL, Maryanti E, F. A. (2020). The Effectivity of Nutrition Education Booklet on Knowledge, Fast-food Consumption, Calorie Intake, and Body Mass Index in Adolescents. Journal of Health Promote Behavior, 5(1), 11-17.

Sood, S., Shefner-Rogers, C., \& Skinner, J. (2014). Health communication campaigns in developing countries. Journal of creative communications, 9(1), 67-84.

Truman, Emily, C. E. (2019). Identifying Food Marketing to Teenagers: a scoping review. International Journal of Behavioral Nutrition and Physical Activity.

Umar, Abdullah B, Tracy J. Koehler, Reian Zhang, Veronica Gilbert, Muhammad U. Farooq, Alan T. Davis, D. N. and P. B. G. (2019). Stroke Knowledge among Middle and High School Students. Journal of International Medical Research, 47(9), 4230-4241.

Upendra Kumar Singh, Nirmal Gautam, Tulsi Ram Bhandari, N. S. (2020). Educational Intervention of Intention Change for Consumption of Junk Food among School Adolescents in Birgunj 
Metropolitan City, Nepal, Based on Theory of Planned Behaviors. Journal of Nutrition and Metabolism, 7.

Vardanjani, Ali Esmaeli, Mahnoush Reisi, Homamodin Javadzade, Zabihollah Gharli Pour, E. T. (2015). The Effect of nutrition education on knowledge, attitude, and performance about junk food consumption among students of female primary schools. Journal of Education and Health Promotion, 4(53).

Weigel, F. K., Rainer, R. K., Hazen, B. T., Cegielski, C. G., \& Ford, F. N. (2012). Use of diffusion of innovations theory in medical informatics research. International Journal of Healthcare Information Systems and Informatics (IJHISI), 7(3), 44-56.

Witt, M., \& Barnett, P. (2012). Assessing the capacity of New Zealand health promoters to develop programs that meet the health literacy needs of both consumers and government. Health promotion journal of Australia : official journal of Australian Association of Health Promotion Professionals, 23(2), 117-121. https://doi.org/10.1071/he12117

Yeravdekar, R., Yeravdekar, V. R., Tutakne, M. A., Bhatia, N. P., \& Tambe, M. (2013). Strengthening of primary health care: Key to deliver inclusive health care. Indian journal of public health, 57(2), 59.

Younis, Fareha Hamd, S. M. E. (2019). Fast Food Consumption among Teenagers Aged Between (13 To 25) Years Old and Their Effect on Health in Derna-Libya. Journal of Regenerative Biology and Medicine, 1(1), 1-8. 